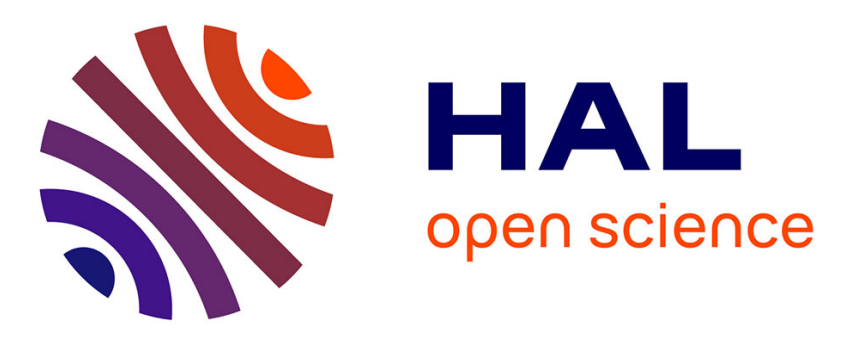

\title{
Detrimental copper-selenide bulk precipitation in CuIn1-xGaxSe2 thin-film solar cells. A possible reason for the limited performance at large $\mathrm{x}$ ?
}

Polyxeni Tsoulka, Nicolas Barreau, Isabelle Braems, Ludovic Arzel, Sylvie Harel

\section{To cite this version:}

Polyxeni Tsoulka, Nicolas Barreau, Isabelle Braems, Ludovic Arzel, Sylvie Harel. Detrimental copperselenide bulk precipitation in CuIn1-xGaxSe2 thin-film solar cells. A possible reason for the limited performance at large x?. Thin Solid Films, 2020, 712, pp.138297. 10.1016/j.tsf.2020.138297 . hal02945507

\section{HAL Id: hal-02945507 \\ https://hal.science/hal-02945507}

Submitted on 25 Nov 2020

HAL is a multi-disciplinary open access archive for the deposit and dissemination of scientific research documents, whether they are published or not. The documents may come from teaching and research institutions in France or abroad, or from public or private research centers.
L'archive ouverte pluridisciplinaire HAL, est destinée au dépôt et à la diffusion de documents scientifiques de niveau recherche, publiés ou non, émanant des établissements d'enseignement et de recherche français ou étrangers, des laboratoires publics ou privés. 


\section{Detrimental copper-selenide bulk precipitation in $\mathrm{CuIn}_{1-\mathrm{x}} \mathrm{Ga}_{\mathrm{x}} \mathrm{Se}_{2}$ thin-film}

\section{2 solar cells. A possible reason for the limited performance at large $\mathbf{x}$ ?}

4 Polyxeni Tsoulka, Nicolas Barreau, Isabelle Braems, Ludovic Arzel, Sylvie Harel

Institut des Materiaux Jean Rouxel (IMN), UMR 6502 CNRS, Université de Nantes 2 rue de la

Houssiniere BP 32229, 44322 Nantes cedex 3, France.

\section{Abstract}

10 In this paper, we propose a possible explanation of the limited $\mathrm{CuIn}_{1-\mathrm{x}} \mathrm{Ga}_{\mathrm{x}} \mathrm{Se}_{2}$ (CIGSe) performance at

11 high $\mathrm{Ga}$ contents, related to the properties of detrimental copper selenide $\left(\mathrm{Cu}_{\delta} \mathrm{Se}\right)$ secondary phases. We

12 study CIGSe layers at different $\mathrm{x}$, by means of X-ray diffraction analyses, Raman and energy dispersive

13 X-ray spectroscopy. Our results reveal that for high $\mathrm{Ga}$ contents, $\mathrm{Cu}_{\delta} \mathrm{Se}$ secondary phases either

14 precipitate at the interfaces between grains or remain within the layer as intra- or inter-grain clusters,

15 deteriorating the electronic properties of the absorber layer. On the contrary, for low Ga contents, the

16 copper selenide segregates at the surface of the CIGSe and hence it can be easily removed by $\mathrm{KCN}$

17 surface etching. To understand the $\mathrm{Cu}_{\delta} \mathrm{Se}$ precipitation within the bulk of the film for a high Ga ratio, we

18 also investigate In-free CGSe samples at low and high $\mathrm{Cu}$ content. Our observations demonstrate that i)

$19 \mathrm{Cu}_{\delta} \mathrm{Se}$ has a preferential grain orientation to segregate and ii) the $\mathrm{Cu}$-enriched regions within the bulk of

20 the high Ga content films are more a kinetic than a thermodynamic issue.

22 Keywords: Copper indium gallium di-selenide; Thin films; Surface segregation; Bulk precipitation;

23 Copper-selenium; Gallium ratio; Physical vapor deposition 


\section{1. Introduction}

2 Polycrystalline $\mathrm{CuIn}_{1-\mathrm{x}} \mathrm{Ga}_{\mathrm{x}} \mathrm{Se}_{2}$ (CIGSe)_absorber layers count among the most promising materials in the

3 field of thin-film solar cells. The CIGSe alloy can be described as a mixture of two ternary I-III-VI

4 semiconductors, $\mathrm{CuInSe}_{2}$ (CISe) and $\mathrm{CuGaSe}_{2}$ (CGSe), where the group III lattice sites are randomly

5 occupied by In or Ga [1-3] and $x$ corresponds to the Ga content:

$$
x=\frac{[\mathrm{Ga}]}{[\mathrm{Ga}]+[\mathrm{In}]}
$$

7 The optical band gap energy $\left(E_{g}\right)$ of the absorber layer can be tuned by substituting Ga to In, from

$8 E_{g}=1.04 \mathrm{eV}$ for Ga-free CISe absorber layer $(x=0)$ to $1.68 \mathrm{eV}$ for In-free CGSe $(x=1)[3,4]$.

9 In recent years, there has been considerable interest in the wide band gap materials like CGSe, since

10 these absorber layers can be used $i$ ) to reach higher output voltage [4] and ii) as the top cell of a tandem

11 stacked-type solar cell [5]. So far, the best lab-scale energy conversion efficiencies of CIG(S)Se-based

12 solar cells are achieved for narrow band gap (23.35\% for CIG(S)Se record efficiency [6]). Theoretically,

13 the optimum Ga ratio to achieve the maximum conversion efficiency is around $x \sim 0.7[7,8]$. However,

14 experimentally the efficiency of the CIGSe-based solar cells strongly decreases when $x$ exceeds the

15 threshold value of $0.4[4-6,8]$.

16 The limited performance of Ga-rich $(x>0.4)$ solar cells is under question for more than 25 years. The

17 experimental and theoretical explanations behind the decreased photovoltaic performance at large $x$ can

18 be divided into two categories $i$ ) the detrimental recombination effects at CIGSe interfaces i.e. the

19 CIGSe surface [9] and grain boundaries (GB) [10-12] and ii) the increased concentration of defects

20 within the bulk of the film [4,13-15] that act as recombination centers.

21 Many experimental studies have shown that crystal defects $[11,15,16]$, secondary phases and local

22 inhomogeneities [17-20] can be created during the CIGSe deposition process at the inter- or intra-grain

23 regions, i.e. segregation or precipitation phenomena at the grain boundaries or within the bulk. $\mathrm{Cu}-$

24 enriched regions or copper-selenide phases can be formed at the surface or/and within the bulk of the 
1 CIGSe film at the inter- or intra-grain regions [11, 21-26]. The copper-selenide secondary phase

2 possesses a semi-metallic character that enhance the charge transfer and acts as electron-hole

3 recombination center. The excess of $\mathrm{Cu}$ at these regions increases the conductivity and creates an

4 electric shunt. Hence, the electrical and optical properties of the absorber layer are negatively impacted

5 [26-28], leading to the deterioration of the solar cell.

6 Copper-selenide secondary phases at the surface and at the inter-grain regions of the absorber layer have

7 been observed in slightly Cu-rich CGSe layers by Kelvin probe force microscopy in [26] and by

8 transmission electron microscopy (TEM) coupled with energy dispersive X-ray dispersion spectroscopy

9 (EDS) in [27,29]. Additionally, studies of high-resolution scanning transmission electron microscopy

10 (HR-STEM) on CIGSe layers [25] have shown the existence of copper-selenide inter- or intra-grain

11 clusters. Further, a model based on $\mathrm{Cu}$-poor and $\mathrm{Cu}$-rich nanodomains creating a network has been

12 proposed in $[19,20]$.

13 In this paper, we focus on the formation of the detrimental $\mathrm{Cu}$-enriched regions in the wide band gap

14 CIGSe and CGSe compounds. We correlate the formation of the copper-selenide detrimental phase with

15 the Ga ratio and we propose an approach that explains the degradation of the photovoltaic performance

16 at large $x$.

17 The remainder of the paper is organized as follows:

18 Section 2 describes the co-evaporation process that we followed to synthetized the CIGSe and CGSe

19 layers, the post-deposition treatments and the instruments that we used for our experimental analyses.

20 Section 3.1 examines two CIGSe films of intermediate $x$ and correlates the surface segregation and bulk

21 precipitation phenomena of the copper-selenide with the Ga ratio. In Section 3.2, we study the copper

22 selenide surface segregation mechanism and bulk precipitation in the case of In-free CGSe films at low

23 and high $\mathrm{Cu}$ contents. Section 4 explains the observed copper selenide precipitation phenomena in the

24 CIGSe layer from a kinetic point of view and proposes some directions for further research in order to 
1 ameliorate the solar cell efficiency of the wide band gap CIGSe. Finally, the main conclusions of this

2 study are drawn in Section 5.

\section{2. Experimental}

5 In our work, to investigate whether the $\mathrm{Cu}$-enriched regions are related to the Ga content of the layer or

6 not, we study the homogeneity of the absorber layer and the presence of the detrimental copper selenide

7 phases in CIGSe layers of intermediate $(x=0.3$ and 0.6$)$ and In-free $(x=1)$ layers.

\section{$8 \quad 2.1$ CIGSe co-evaporation process}

9 In the present work, the absorber layers are synthesized by physical vapor deposition (PVD) process

10 under vacuum $\left(\sim 10^{-4} \mathrm{~Pa}\right)$. During the CIGSe deposition process the flux (atoms per time unit) and the

11 arrival rate per unit area of each element is controlled in order to obtain the desirable $i$ ) CIGSe thickness

$12(1.5-2.0 \mu \mathrm{m})$, ii) $\mathrm{Ga}$ to In ratio $(x)$ and $i i i) \mathrm{Cu}$ to group-III atoms ratio $(y)$ :

$$
y=\frac{[\mathrm{Cu}]}{[\mathrm{Ga}]+[\mathrm{In}]}
$$

14 IR lamps were used as substrate heaters and the temperature was measured by a thermocouple in contact

15 with the back of the substrate. To avoid a possible $\mathrm{Ga}$ gradient within the layer and focus only on the $\mathrm{Cu}$

16 diffusion, the $\mathrm{Cu}-\mathrm{RO}$ process was chosen to synthesize the CIGSe films. The $\mathrm{Cu}-\mathrm{RO}$ technique is a two-

17 stage isothermal $\left(T=560^{\circ} \mathrm{C}\right)$ process which starts with a Cu-Rich step (Stage I, $\left.y>1\right)$ and continues with a

18 Cu-poor step (Stage II, $y<1$ ). The phase diagram of the ternary CISe compound [30, 31] shows that the

19 chalcopyrite $\alpha$-phase is stable from $y=0.91$ to 1 and that the homogeneous $\alpha$-phase broadens with Na-

20 doping and/or Ga to In substitution [32]. As regards the CGSe phase diagram [33, 34], the chalcopyrite

21 phase is stable for $y$ between 0.73 and 1 . However, in both cases, the ternary phase diagrams reveal that

22 for $y>1$ the chalcopyrite phase co-exists with the copper-selenide compounds $\left(\mathrm{CuSe}_{2}, \mathrm{CuSe} \mathrm{Cu}_{\delta} \mathrm{Se}\right)$.

23 Hence, to keep the semiconductor character and avoid the presence of semi-metallic copper-selenide 
1 secondary phases the final composition of the absorber layer is slightly $\mathrm{Cu}-$ poor $(y<1)$. However, it

2 should be noted that the thermodynamic equilibrium may not be reached during the CIGSe deposition

3 process and hence the presence of secondary phases, such as the detrimental copper-selenides. During

4 the whole co-evaporation process the Se flux is in excess and the overall deposition rate is $30 \mathrm{~nm} / \mathrm{min}$.

5 More details about the $\mathrm{Cu}-\mathrm{RO}$ co-evaporation technique can be found in [35]. A single-stage co-

6 evaporation process at $560^{\circ} \mathrm{C}$ substrate temperature was also carried out to study separately the case of a

7 Cu-rich CGSe layer.

8 The CIGSe layers of intermediate $x$ were deposited on soda-lime glass (SLG)/Si ${ }_{\mathrm{x}} \mathrm{N} / \mathrm{Mo}$ substrate at

$9560^{\circ} \mathrm{C}$. The $\mathrm{Si}_{\mathrm{x}} \mathrm{N}$ layer serves as an alkali diffusion barrier. Studies have shown that Na diffusion within

10 the CIGSe layer, hinders the In-Ga interdiffusion $[36,37,38]$. Hence, to avoid any possible Ga grading

11 within the CIGSe layers of intermediate $\mathrm{x}$, the absorbers were co-evaporated on soda-lime glass

12 (SLG)/Na-barrier( $\left.\mathrm{Si}_{\mathrm{x}} \mathrm{N}\right) / \mathrm{Mo}$ substrate. The In-free CGSe layers were deposited on standard SLG/Mo

13 substrates.

\section{$14 \quad 2.2$ Post-deposition treatments}

15 After the end of the co-evaporation process, we applied a wet-chemical etching of the CIGSe surface

16 using a potassium cyanide $(\mathrm{KCN})$ solution [39] in order to remove any possible surface segregated $\mathrm{Cu}-$

17 rich secondary phases. Here, we should notice that the $\mathrm{KCN}$ etching removes only the copper selenides

18 from the surface, without acting on any possible $\mathrm{Cu}$-rich compound in the bulk or the inter-grain regions

19 of the CIGSe film [26-28]. Finally, after the KCN etching some of the samples were annealed under

20 vacuum at $350^{\circ} \mathrm{C}$ for $24 \mathrm{~h}$ or 30 days in order to reach the thermodynamic equilibrium and avoid the

21 presence of secondary phases. Table I summarizes the samples that we used in our study.

\section{$22 \quad$ 2.3 Characterization}


1 The composition of the CIGSe layer was measured by EDS coupled with a SEM (scanning electron

2 microscope) using a JEOL JSM 5800LV at $5 \mathrm{kV}$ (surface analysis) and $20 \mathrm{kV}$ (bulk analysis)

3 acceleration voltage. In-line cross-section elemental profile was also performed on one of our samples

4 (\#04) using SEM-EDS at $10 \mathrm{kV}$ acceleration voltage. The cross-section analyzed area was mechanically

5 polished using the ultramicrotome Leica UC7 equipped with a diamond knife. For the high resolution

6 SEM images a JEOL JSM 7600F microscope was used.

7 Raman spectroscopy was applied for the chemical analysis of the near surface region of the CIGSe

8 layers (surface analysis). The system used is a Renishaw InVia Reflex and the wavelength of the

9 excitation beam was set to $488 \mathrm{~nm}$ using an $\mathrm{Ar}^{+}$laser source. The interaction depth at $488 \mathrm{~nm}$ excitation

10 wavelength corresponds to less than $150 \mathrm{~nm}$.

11 The structural observation of the CIGSe films was based on an XRD (X-ray diffraction) study, with a

12 Siemens D8 integrated with a Cu-Ka source radiation $(\lambda=1.54056 \AA)$.

14 3. Results

15 3.1 Copper selenide precipitation phenomena in CIGSe layers of intermediate $x$

16 In the present section, we study the samples of intermediate Ga content (sample \#01 with $x=0.30$ and

$17 \# 02$ with $x=0.60)$ and the creation of $\mathrm{Cu}$-enriched local inhomogeneities within the bulk of the CIGSe

18 layers.

19 The CIGSe layers were deposited on $\mathrm{SLG} / \mathrm{Si}_{\mathrm{x}} \mathrm{N} / \mathrm{Mo}$ using the $\mathrm{Cu}-\mathrm{RO}$ process. After the end of the co-

20 evaporation process, the samples were $\mathrm{KCN}$-etched, sealed under vacuum in a quartz tube and annealed

21 at $350^{\circ} \mathrm{C}$ for 30 days.

$22 \quad-\quad$ Surface morphology

23 The CIGSe surface morphology of the samples without any post deposition treatment is shown in Figure

24 1. The Sample \#02 $(x=0.60)$ presents a rough surface and an important amount of grains with a 
1 triangular morphology. According to [40,41] the faceted grains are $\{112\}$-oriented and the ledges of the

2 triangles correspond to $\{220\} /\{204\}$ planes. The $x=0.30$ samples present a smoother surface than the

$3 x=0.60$ ones. Figure 2 gives a high-magnification SEM image of the surface after the KCN treatment and

4 the annealing.

5 On the $x=0.30$ annealed sample, we observe the existence of voids at the surface which are created by

6 the removal of the copper-selenide phases after the $\mathrm{KCN}$ surface etching. This observation is in line with

7 the EDS analysis (see table I), which shows that after the $\mathrm{KCN}$ treatment and annealing, the overall $\mathrm{Cu}$

8 content is decreased from $y=0.98$ to 0.92 , due to the copper-selenide removal after the KCN etching. In

9 contrast, on the CIGSe $x=0.60$ annealed sample the $\mathrm{Cu}$ content did not significantly change (from

$10 y=0.87$ to 0.86 ) after the $\mathrm{KCN}$ treatment and the annealing. Moreover, in Figure 2 we can see small

11 clusters aligned along precise orientations of grains having the ledge-patterned morphology.

\section{- Copper selenide surface segregation in CIGSe of intermediate $x$}

13 To identify the probable existence of different phases at the surface of the CIGSe film and investigate

14 the chemical composition of the ledge-patterned grains containing the clusters, we performed a Raman

15 analysis (see Fig. 3) at the upper CIGSe layers. The Raman peak at $175 \mathrm{~cm}^{-1}$ for the $x=0.30$ CIGSe film

16 and at $179 \mathrm{~cm}^{-1}$ for 0.60 is related to the main $\mathrm{A}_{1}$ CIGSe vibration mode $[42,43]$ of the Se anions. The

17 two spectra also depict the weak $\mathrm{B}_{2} / \mathrm{E}$ stretching In/Ga-Se mode $[42,43]$ around $216 \mathrm{~cm}^{-1}$ and $239 \mathrm{~cm}^{-1}$

18 for $x=0.30$ and around $226 \mathrm{~cm}^{-1}$ and $242 \mathrm{~cm}^{-1}$ for $x=0.60$. The shift of chalcopyrite peaks at larger

19 wavenumber, observed for $x=0.60$, is due to the decrease of the lattice parameters [44] of the high Ga

20 content crystals. The additional peak at $259 \mathrm{~cm}^{-1}$ corresponds to the $\mathrm{A}_{1}$ vibration mode of a copper-

21 selenide compound as the $\mathrm{CuSe}, \mathrm{Cu}_{2} \mathrm{Se}$ or $\mathrm{Cu}_{2-\delta} \mathrm{Se}$, according to [42, 43, 45]. Moreover, our results show

22 that after the end of the co-evaporation process both samples exhibit a copper-selenide phase at the

23 surface, while after the $\mathrm{KCN}$ chemical etching and the annealing only the Ga-rich $(x=0.60)$ sample 
1 presents a copper-selenide phase at the surface. In the In-rich sample there is no $\mathrm{Cu}$-Se Raman peak after

2 the post-deposition $\mathrm{KCN}$ treatment and the annealing.

3 Comparing the black lines in Figures $3 \mathrm{a}$ and $3 \mathrm{~b}$, we notice that prior to the $\mathrm{KCN}$ etching and the

4 annealing, the intensity of the $\mathrm{Cu}_{\delta} \mathrm{Se}$ peak is more pronounced for the sample with $x=0.60$ than for the

5 one with $x=0.30$, indicating a larger $\mathrm{Cu}$ content. This observation could be related with the smoother

6 surface observed for $x=0.30$ (see Fig. 1).

7 The red lines correspond to the Raman spectra after the KCN treatment and the annealing. Within the

$8 x=0.30$ all the $\mathrm{Cu}_{\delta} \mathrm{Se}$ was removed from the CIGSe surface after the KCN etching and no further $\mathrm{Cu}_{\delta} \mathrm{Se}$

9 accumulation was observed at the CIGSe upper layers after the annealing. In contrast, the $x=0.60 \mathrm{KCN}$

10 treated and annealed sample presents a $\mathrm{Cu}_{\delta} \mathrm{Se}$ compound at the surface after the annealing, which could

11 be related with the aligned clusters observed at the CIGSe surface after the annealing (Fig. 2) as

12 mentioned above.

13 Thus, comparing the $x=0.60$ (Ga-rich CIGSe) Raman spectra before and after the post deposition

14 treatment, it can be assumed that there are $\mathrm{Cu}_{\delta}$ Se precipitates in the bulk of the Ga-rich $(x=0.60)$ layer

15 after the end of the CIGSe co-evaporation process and the KCN etching. Hence, after the annealing

16 where the thermodynamic equilibrium has been reached, the bulk-precipitated $\mathrm{Cu}_{\delta} \mathrm{Se}$ segregates at the

17 surface. Thus, the copper selenide peak in Raman spectra after the post deposition treatment corresponds

18 to the $\mathrm{Cu}_{\delta} \mathrm{Se}$ phase that has segregated at the surface after the annealing. In contrast this is not the case

19 for $x=0.30$ (In-rich CIGSe), since there is no $\mathrm{Cu}_{\delta} \mathrm{Se}$ peak in the Raman spectra after the KCN treatment

20 and the annealing, indicating that all the $\mathrm{Cu}_{\delta} \mathrm{Se}$ was segregated at the surface after the end of the co-

21 evaporation process, and removed afterwards by the $\mathrm{KCN}$ treatment. Hence, no $\mathrm{Cu}_{\delta} \mathrm{Se}$ remained trapped

22 in the bulk of the film after the CIGSe deposition process.

23 - CIGSe texture 
1 The XRD diffractograms (Fig. 4) do not show any copper selenide peak and the only identified phase is

2 the chalcopyrite. This raises questions about the $\mathrm{Cu}_{\delta} \mathrm{Se}$ form within the bulk, since it could be present as

3 an amorphous phase at the inter- or intra-grain region or as small crystallites that cannot be detected with

4 the XRD analysis.

5 The diffractograms show that the CIGSe layers are mainly (112)-oriented (peak at $26.9^{\circ}$ for $x=0.30$ and

6 at $27.2^{\circ}$ for $x=0.60$ ) and none of the samples presents a peak related to a copper-selenide phase. The shift

7 of the (112) peak to higher angles for $x=0.60$ indicates that the lattice parameters are decreased

8 compared to $x=0.30$. In our case the resulting (112) preferential orientation strongly depends on the high

9 isothermal deposition temperature and the texture of the $\mathrm{Cu}$-rich precursor layer, where the $\mathrm{cubic} \mathrm{Cu}_{2} \mathrm{Se}$

10 and tetragonal non-stoichiometric $\mathrm{Cu}_{\delta} \mathrm{Se}$ phases are (111)-oriented.

11 Examining the samples before and after annealing reveals that the full width at half maximum (FWHM)

12 of the (112) orientation is decreasing after the annealing (FWHM $\left.(112)_{\text {before }}-\operatorname{FWHM}(112)_{\text {after }}=0.01^{\circ}\right)$

13 which indicates a grain size enlargement.

\section{Proposed scenario: Detrimental copper-selenide bulk precipitation at large $x$}

15 The comparison between the $x=0.30$ and $x=0.60$ XRD and Raman data leads us to conclude that the $\mathrm{Cu}-$

16 Se segregation phenomena differ for low and high Ga ratios: in the Ga-rich sample there are $\mathrm{Cu}_{\delta} \mathrm{Se}$

17 precipitates within the bulk after the end of the co-evaporation process, contrary to the In-rich sample

18 where the whole $\mathrm{Cu}_{\delta} \mathrm{Se}$ has segregated at the surface. A longer annealing is then required for $x=0.60$ to

19 make the entire $\mathrm{Cu}_{\delta} \mathrm{Se}$ segregate at the surface. In addition the fact that no $(\mathrm{In}, \mathrm{Ga})_{2} \mathrm{Se}_{3}$ or other $\mathrm{Cu}$-poor

20 phases (i.e. $\left.\mathrm{Cu}(\mathrm{In}, \mathrm{Ga})_{3} \mathrm{Se}_{5}\right)$ were observed after the annealing, reveals that copper selenide compounds

21 observed at the surface after the annealing came from the bulk and no (In, Ga) ${ }_{2} \mathrm{Se}_{3}-\mathrm{Cu}_{2} \mathrm{Se}_{\mathrm{phase}}$

22 separation occurred during the annealing. Figure 5 presents a schematic model of $\mathrm{Cu}_{\delta} \mathrm{Se}$ behavior in the

23 case of low $(x=0.30)$ and high $(x=0.60)$ Ga content, before and after the post-deposition treatment.

\section{$24 \quad 3.2$ Bulk precipitation and surface segregation phenomena in $\mathrm{CuGaSe}_{2}$}


1 To further understand the cause of the copper-selenide bulk precipitation observed in CIGSe layers with

2 large Ga ratios, we focus on In-free CGSe layers with high and low $\mathrm{Cu}$ content and we investigate the

$3 \mathrm{Cu}_{\delta} \mathrm{Se}$ segregation mechanism and the crystallinity of the copper-selenide compounds at the surface and

4 within the layer.

\section{- $\quad \mathrm{Cu}_{\delta} \mathrm{Se}$ surface segregation via a precise grain orientation}

6 To study the $\mathrm{Cu}_{\delta} \mathrm{Se}$ surface segregation in the case of high Ga contents, we perform a surface SEM-EDS

7 cartography on a Cu-rich ( $y>1)$ CGSe sample (\#03) before and after annealing. The layer was deposited

8 using a single-stage process, resulting in a final CGSe layer with $y=1.50$. After the end of the deposition

9 process the sample was annealed for $24 \mathrm{~h}$ at $350^{\circ} \mathrm{C}$ under vacuum.

10 Figure 6 shows SEM images of the Cu-rich surface before and after the annealing. As shown in Figure

11 6a, the surface of the sample before annealing presents two main types of grains: $i$ ) smooth single

12 faceted grains and ii) rough grains where periodic steps create a ledged patterned surface. In the surface

13 of the annealed sample (Fig. $6 \mathrm{~b}$ and $6 \mathrm{c}$ ) small clusters accumulate at the ledges of the rough grains.

14 Recall that the same phenomenon was observed for the Ga-rich sample (see Fig. 2 in Section 3.1).

15 Further an EDS cartography was carried out at $5 \mathrm{kV}$ acceleration voltage, in order to decrease the

16 interaction depth of the electron beam and be able to analyze only the upper layers of the surface. Using

17 the Casino software [46], we carried out a Monte Carlo simulation (not shown here) of the interaction

18 volume of our SEM-EDS analysis at $5 \mathrm{kV}$ beam energy and we found that the interaction depth is

19 around $150 \mathrm{~nm}$. The EDS cartography (see Fig. 7) revealed that the upper layers of the grains containing

20 the clusters on their surface are $\mathrm{Cu}$-rich. Thus, we conclude that the $\mathrm{Cu}_{\delta} \mathrm{Se}$ has a preferential grain

21 orientation to segregate, since after the annealing, it accumulates only at the ledges of the $\{112\}$-oriented

22 grains with the precise step-patterned surface.

$23 \quad$ - Crystallinity of the bulk-precipitated $\mathrm{Cu}_{\delta} \mathrm{Se}$ phase 
1 Here, we examine the presence of $\mathrm{Cu}$-rich regions within the layer of slightly $\mathrm{Cu}$-poor CGSe samples

2 and we investigate the $\mathrm{Cu}_{\delta} \mathrm{Se}$ form in the bulk. The CGSe samples were synthesized by a two-stage $(\mathrm{Cu}-$

3 RO) co-evaporation process on Mo ( $\# 04, y=0.95$ ) the sample was chemically etched with $\mathrm{KCN}$ after the

4 end of the deposition process. Figure 8 depicts the XRD diffractogram of the CGSe sample (\#04) with

$5 y=0.95$ grown on $\mathrm{Mo}$ and no peak of $\mathrm{Cu}_{\delta} \mathrm{Se}$ is apparently observed. However, the in-line cross-section

6 elemental profile, using a SEM-EDS at $10 \mathrm{kV}$ acceleration voltage (Fig. 9), presents a small variation of

7 the $\mathrm{Cu}$ content, resulting in a slight $\mathrm{Cu}$-rich region close to the back contact. The fact that the XRD

8 analysis of the sample did not indicate any $\mathrm{Cu}_{\delta} \mathrm{Se}$ peak, while the EDS cross-section profile detects a

9 Cu-rich region, leads us to the conclusion that the $\mathrm{Cu}_{\delta} \mathrm{Se}$ precipitates in the bulk are present in an

10 amorphous form. However, this assumption does not exclude a possible $\mathrm{Cu}_{\delta} \mathrm{Se}$ precipitation at the inter-

11 grain regions or the existence of small not-detectable crystallites within the grains.

\section{4. Discussion}

14 In this paper, we examined the copper-selenide precipitation and the presence of $\mathrm{Cu}$-rich secondary 15 phases in regard to the Ga content of the thin films. Our investigations suggest that for large Ga ratios 16 ( $x>0.4$ ), copper-selenide compounds precipitate within the bulk of the film or/and close to the back 17 contact, whereas for low $\mathrm{Ga}$ contents the whole undiluted $\mathrm{Cu}_{\delta} \mathrm{Se}$ segregates at the surface. This is a vital 18 issue for future research in the wide band gap CIGSe absorber layers since the Cu-rich regions within 19 the bulk could be a possible explanation of the observed photovoltaic degradation at large Ga contents $20 \quad$ (when $x>0.4$ ).

21 Our observations are consistent with the findings in [19] where the cubic $\mathrm{Cu}_{2} \mathrm{Se}$ phase was observed by 22 TEM-EDS micro-analysis, on the CIGSe surface and the $\mathrm{Cu}_{2-\delta} \mathrm{Se}$ tetragonal phase at the interface 23 between the grains. Additionally, in [11] an atom probe tomography (APT) analysis on CIGSe revealed 24 the presence of $\mathrm{Cu}$-enriched grain boundaries when $x>0.8$ and In-enriched GBs for $x<0.4$. 
1 Our studies have also shown that the copper selenide is facilitated by a precise orientation of the grains.

2 This observation could be correlated with the findings in [25], where studies of HR-STEM and electron

3 energy-loss spectroscopy revealed the presence of platelets of copper selenides within the grains, 4 parallel to the $\{112\}$ planes of the CIGSe.

5 An interesting question to address is how is it possible to have $\mathrm{Cu}$-enriched regions in a stoichiometric 6 or slightly $\mathrm{Cu}$-poor $(y<1)$ film of large Ga content, since according to the CISe, CGSe and CIGSe [30-

$7 \quad 34,47,48]$ phase diagrams the copper selenide phase is formed and co-exists with the chalcopyrite phase

8 only when $y>1$. For $y<1$ there is only the co-existence of Cu-poor CIGSe compositions with the 9 chalcopyrite phase. Taking into account, that $i$ ) during the deposition process we are not under 10 thermodynamic equilibrium and $i$ ) the CISe and CGSe kinetic properties differ [38,49-51], we can 11 assume the creation of local inhomogeneities during the CIGSe formation. Moreover, of particular 12 interest is the fact that only in the case of Ga-rich film a long annealing is needed to make the copper13 selenide segregate at the surface.

14 In contrast, for the In-rich CIGSe synthesis, the duration of the deposition process is sufficient to make

15 the excess of copper segregate at the surface, resulting in a homogeneous and close to stoichiometry 16 bulk composition of the film. The same result is also observed in the In-free CGSe layer of $y>1$ where 17 segregated clusters are observed at the step-patterned grains after an annealing of 24 hours. Hence, the 18 Cu-rich precipitates within the bulk of the Ga-rich films is more a kinetic than a thermodynamic issue. 19 As highlighted in our previous paper [52] for the CGSe wide band gap solar cells, applying two 20 annealing stages during the 3-stage ( $\mathrm{Cu}$ Poor-Rich-Off) process results in an improved lateral uniformity

21 of the metal atoms and better solar cell device performance (the current density is increased by $11.2 \%$

22 and the solar cell efficiency by $8 \%$. In [52] the Raman analysis at the front and rear surface of CGSe

23 samples with and without annealing stages show that the absorber synthesized without any annealing

24 step presents a nonuniform $\mathrm{Cu} / \mathrm{Ga}$ distribution and higher amount of $\mathrm{Cu}$ at the rear surface, while the 
1 CGSe sample synthesized with two relaxation stages during the growth exhibits homogeneous $\mathrm{Cu} / \mathrm{Ga}$

2 distribution. Similarly, another previous study [53] on CGSe samples grown with and without relaxation

3 stages by a $\mathrm{Cu}-\mathrm{RO}$ process and analyzed by Raman spectroscopy at the front and rear CGSe surface

4 indicate an improved homogeneity and solar cell efficiency when the relaxation stage is applied during

5 the growth.

6 Considering $i$ ) the different electronegativity between Ga and In, ii) the structural CIGSe variation with

7 the Ga content $(x)$ and $i i i)$ the different reaction pathways and reaction speed of the two pure ternary

8 compounds [38, 50,51], it can be assumed that different precipitation and segregation phenomena will

9 take place at low and high $x$. Taking into account previous studies on the thermodynamic and kinetic

10 properties of CISe and CGSe, it appears more probable to have local inhomogeneities and secondary

$11 \mathrm{Cu}$-rich phases in the case of high Ga contents, since:

12 i) The reaction rates of CISe and CGSe are different, CGSe being formed much slower than CISe 13 at a given temperature $[49,54]$. In fact, in [49, 54], studies on the formation rates of CISe and CGSe by

14 selenization of $\mathrm{Cu} / \mathrm{In}$ and $\mathrm{Cu} / \mathrm{Ga}$ precursors, respectively, demonstrated that the time to form CGSe by 15 selenization of a $\mathrm{Cu} / \mathrm{Ga}$ precursor at $500^{\circ} \mathrm{C}$ is six times larger than the formation of CISe [49] and that at $16400^{\circ} \mathrm{C}$ the CISe needs 30 min to be formed when CGSe needs 90 min at $450^{\circ} \mathrm{C}^{[52]}$.

17 ii) Studies of the CGSe and CISe reaction kinetics using isothermal soak of glass/GaSe/CuSe and 18 glass/InSe/CuSe precursors, show that the activation energy of the CGSe formation is larger than the 19 activation energy of CISe (115 kJ/mol and $66 \mathrm{~kJ} / \mathrm{mol}$, respectively) [50, 51].

20 Hence, given that the $\mathrm{Cu}$-enriched regions within the bulk of the Ga-rich layer are a kinetic issue and the 21 copper selenide surface segregation takes place via a precise orientation of the grains, special attention 22 should be taken to the deposition process for Ga-rich CIGSe layers in order to:

23 a) Control the texture of the CIGSe film. 
1 Studies on the CIGSe deposition process have shown that the preferential orientation of the CIGSe

2 films depends on: a) the alkali impurities such as $\mathrm{K}$ and $\mathrm{Na}$, that diffuse via the SLG substrate [55-59] b)

3 the Se flux during the co-evaporation process [40, 58-60], c) the deposition temperature [56, 57, 59] and

4 d) $\mathrm{Cu}$ concentration $[56,57,61]$.

b) Enhance the interdiffusion of the elements in order to obtain a more homogeneous absorber layer.

7 The presence of a high amount of $\mathrm{Ga}$ in the CIGSe lattice seems to weaken the interdiffusion of 8 elements and so it could be responsible for the creation of secondary intra-grain phases as the $\mathrm{Cu}_{\delta} \mathrm{Se}$. In

9 [8], it was observed that for $0.3<x<1$, the CIGSe films presented higher efficiencies for substrate 10 temperatures higher $\left(600^{\circ} \mathrm{C}-650^{\circ} \mathrm{C}\right)$ than the commonly used ones $\left(500^{\circ} \mathrm{C}-600^{\circ} \mathrm{C}\right)$.

11 Additionally, attention should be paid on the fact that the annealing of our samples was performed under 12 vacuum. As a result, the observed grain enlargement and homogenization of the film could be also 13 related with the increased amount of Se vacancies that could act as diffusion pathways [54, 62].

\section{5. Conclusions}

16 In this paper, we developed an approach to understand the copper selenide behavior in the CIGSe layer

17 at low and high Ga content. We studied CIGSe samples at intermediate $x(0.3$ and 0.6$)$ and at low $(y<1)$

18 and high $(y>1) \mathrm{Cu}$ content. Our work revealed that the copper selenide segregation phenomena depend

19 on the Ga ratio. We demonstrated that for large $\mathrm{Ga}$ content there are $\mathrm{Cu}$-enriched detrimental precipitates

20 within the bulk of the layer, while for low Ga ratio the whole copper selenide segregates at the surface

21 and then can be easily removed by $\mathrm{KCN}$ wet-chemical etching.

22 We also investigated pure CGSe layers at low and high $\mathrm{Cu}$ contents grown on SLG/Mo. We concluded

23 that the $\mathrm{Cu}$-enriched regions within the bulk of the Ga-rich layer are a kinetic issue and the copper 24 selenide surface segregation mainly occurs via a precise orientation of the grains. 
1 Considering that the $\mathrm{Cu}_{\delta} \mathrm{Se}$ compounds have a metallic character which degrades the electrical

2 properties of the solar cell, our findings could be a possible explanation for the limited photovoltaic

3 performance at high Ga contents. Hence, the copper selenide secondary phases in the CIGSe layer are an

4 important issue for future research.

5 What is known about the $\mathrm{Cu}_{\delta} \mathrm{Se}$ in the CIGSe field is largely based on narrow band gap CIGSe $(x<0.4)$

6 and so, further investigation on the $\mathrm{Cu}_{\delta} \mathrm{Se}$ formation at the Ga-rich CIGSe layers is required. In addition,

7 a re-investigation of the co-evaporation processes should be considered, since for large Ga ratios, the

8 excess of $\mathrm{Cu}$ during the $\mathrm{Cu}$-rich stage seems to create $\mathrm{Cu}$-enriched regions within the bulk, which are

9 not diluted or segregated at the surface during the $\mathrm{Cu}$-poor co-evaporation step. Nevertheless, the $\mathrm{Cu}$ -

10 rich deposition stage is essential for a high quality CIGSe absorber layer, since during this step the

11 mobility and the interdiffusion of the elements is increased, facilitating the grain growth [61].

12 Taken together, the results of our study suggest that the deposition process should be adapted to the

13 needs of the wide band gap CIGSe and CGSe absorbers. To improve the quality of the wide bad gap

14 CIGSe absorbers and obtain high-efficiency solar cells, it is important to: $i$ ) keep the $\mathrm{Cu}$ content as close

15 as possible to stoichiometry $(y=1)$, during the $\mathrm{Cu}$-rich co-evaporation step, $i i)$ control the texture of the

16 CIGSe layer, iii) increase the diffusion pathways by decreasing the Se flux during the process and $i v$ )

17 increase the deposition temperature or/and the duration of the process by adding a relaxation stage or by

18 decreasing the deposition rate, in order to enhance the $\mathrm{Cu}-\mathrm{Ga}$ interdiffusion.

\section{Acknowledgments}

21 This work was supported by the Jean Rouxel Institute of materials and the University of Nantes. We 22 gratefully acknowledge Prof. Angus Rockett, who gave us much valuable advice at the beginning of this 23 work. Thanks is due to Nicolas Stephant and Nicolas Gautier for their technical assistance in our 24 experimental work. 


\section{References}

2 [1] J.E. Jaffe, A. Zunger, Electronic structure of the ternary chalcopyrite semiconductors CuAlS $\mathrm{C}_{2}$

$3 \mathrm{CuGaS}_{2}, \mathrm{CuInS}_{2}, \mathrm{CuAlSe}_{2}, \mathrm{CuGaSe}_{2}$, and CuInSe 2 , Phys. Rev. B 28 (1983) 5822-5847

4 [2] C. Stephan, Structural trends in off stoichiometric chalcopyrite type compound semiconductors, $\mathrm{PhD}$ $5 \quad$ Thesis, Berlin (2011)

[3] T. Tinoco, C. Rincón, M. Quintero, G.S. Pérez, Phase diagram and optical energy gaps for $\mathrm{CuIn}_{\mathrm{y}} \mathrm{Ga}_{1-}$ y $\mathrm{Se}_{2}$ alloys, Phys. Status Solidi (a) 124 (1991) 427-434

[4] S.-H. Wei, S.B. Zhang, A. Zunger, Effects of Ga addition to CuInSe 2 on its electronic, structural, and defect properties, Appl. Phys. Lett. 72 (1998) 3199-3201

[5] S. Nishiwaki, S. Siebentritt, P. Walk, M.Ch. Lux-Steiner, A stacked chalcopyrite thin-film tandem solar cell with 1.2V open-circuit voltage, Prog. Photovoltaics Res. Appl. 11 (2003) 243-248

\section{[6] http://www.solar-frontier.com/eng/news/2019/0117 press.html}

[7] W. Shockley, H.J. Queisser, Detailed balance limit of efficiency of p-n junction solar cells, J. Appl. Phys. 32 (1961) 510-519

[8] M.A. Contreras, L.M. Mansfield, B. Egaas, J. Li, M. Romero, R. Noufi, E. Rudiger-Voigt, W. Mannstadt, Wide bandgap $\mathrm{Cu}(\mathrm{In}, \mathrm{Ga}) \mathrm{Se}_{2}$ solar cells with improved energy conversion efficiency, Progr. Photovolt: Res. Appl. 20 (2012) 843-850

[9] M. Saad, A. Kassis, Thermally and light-activated current in $\mathrm{ZnO} / \mathrm{CdS} / \mathrm{CuGaSe}_{2}$ single crystal solar cells, Renew. Energy 33 (2008) 974-978

[10] H. Mirhosseini, J. Kiss, C. Felser, Behavior of $\Sigma 3$ grain boundaries in $\mathrm{CuInSe}_{2}$ and $\mathrm{CuGaSe}_{2}$ photovoltaic absorbers revealed by first-principles hybrid functional calculations, Phys. Rev. Appl. 4 (2015) 1-6 
1 [11] M. Raghuwanshi, Influence of grain boundary chemistry on the properties of CIGS photovoltaic

2 cells, $\mathrm{PhD}$ Thesis, Rouen (2015)

3 [12] C.-S. Jiang, R. Noufi, K. Ramanathan, J.A. AbuShama, H.R. Moutinho, M.M. Al Jassim, Local

4 built-in potential on grain boundary of $\mathrm{Cu}(\mathrm{In}, \mathrm{Ga}) \mathrm{Se}_{2}$ thin films, Renew. Energy 1 (2005) 245-246

5 [13] J.T. Heath, J. D. Cohen, W.N. Shafarman, D. X. Liao, A.A. Rockett, Effect of Ga content on defect 6 states in CuIn ${ }_{1-\mathrm{x}} \mathrm{Ga}_{\mathrm{x}} \mathrm{Se}_{2}$ photovoltaic devices, Appl. Phys. Lett. 80 (2002) 4540-4542

7 [14] A. Darga, W. Favre, M. Fruzzetti, J.-P. Kleider, B. Morel, D. Mencaraglia, P.Yu, H. Marko, L. 8 Arzel, N. Barreau, S. Noël, J. Kessler, Study of the electronic properties of wide band gap CIGSe 9 solar cells: Influence of copper, J. Non Cryst. Solids 358 (2012) 2428-2430

10 [15] S. Lany, A. Zunger, Limitation of the open-circuit voltage due to metastable intrinsic defects in $11 \mathrm{Cu}(\mathrm{In}, \mathrm{Ga}) \mathrm{Se}_{2}$ and strategies to avoid these defects, Preprint. Renew. Energy (2008) 7-9

12 [16] S. B. Zhang, S.-H. Wei, A. Zunger, H. Katayama-Yoshida, Defect physics of the CuInSe ${ }_{2}$ 13 chalcopyrite semiconductor, Phys. Rev. B - Condens. Matte. Phys. 57 (1998) 9642-9656

14 [17] U. Rau, J.H. Werner, Radiative efficiency limits of solar cells with lateral band-gap fluctuations, Appl. Phys. Lett. 84 (2004) 3735-3737

[18] J.R. Tuttle, D.S. Albin, R. Noufi, Thoughts on the microstructure of polycrystalline thin film $\mathrm{CuInSe}_{2}$ and its impact on material and device performance, Sol. Cells 30 (1991) 21-38

[19] R. Noufi, Y. Yan, J. Abu-Shama, K. Jones, M. Al-Jassim, B. Keyes, J. Alleman, K. Ramanathan, Investigation of the microstructure of $\mathrm{Cu}(\mathrm{In}, \mathrm{Ga}) \mathrm{Se}_{2}$ thin films used in high-efficiency devices, Preprint Renew. Energy (2002) 1-4

[20] Y. Yan, R. Noufi, K.M. Jones, K. Ramanathan, M.M. Al-Jassim, B.J. Stanbery, Chemical fluctuation-induced nanodomains in $\mathrm{Cu}(\mathrm{In}, \mathrm{Ga}) \mathrm{Se}_{2}$ films, Appl. Phys. Lett. 87 (2005) 1-3 
1 [21] T. Wada, N. Kohara, T. Negami, M. Nishitani, Growth of CuinSe ${ }_{2}$ crystals in Cu-rich Cu-In-Se thin

2 films, J. Mater. Res. 12 (1997) 1456-1462

3 [22] D. Abou-Ras, S.S. Schmidt, R. Caballero, T. Unold, H-W. Schock, C.T. Koch, B. Schaffer, M.

4 Schaffer, P.-P. Choi, O. Cojocaru-Mirédin, Confined and chemically flexible grain boundaries in 5 polycrystalline compound semiconductors, Adv. Energy Mater. 2 (2012) 992-998

6 [23] E. Simsek Sanli, Q.M. Ramasse, W. Sigle, D. Abou-Ras, R. Mainz, A. Weber, H.-J. Kleebe, P. A. 7 van Aken, Elemental redistributions at structural defects in $\mathrm{Cu}(\mathrm{In}, \mathrm{Ga}) \mathrm{Se}_{2}$ thin films for solar cells, $\mathrm{J}$. $8 \quad$ Appl. Phys. 120 (2016) 205301

9 [24] T. Schwarz, G. Stechmann, B. Gault, O. Cojocaru-Miredin, R. Wuerz, D. Raabe, Correlative 10 transmission Kikuchi diffraction and atom probe tomography study of $\mathrm{Cu}(\mathrm{In}, \mathrm{Ga}) \mathrm{Se}_{2}$ grain 11 boundaries Prog. Photovolt. Res. Appl. (2017) 1-9

12 [25] E. Simsek Sanli, Q.M. Ramasse, R. Mainz, A. Weber, D. Abou-Ras, W. Sigle, P.A. van Aken, 13 Evidence for $\mathrm{Cu}_{2-\mathrm{x}} \mathrm{Se}$ platelets at grain boundaries and within grains in $\mathrm{Cu}(\mathrm{In}, \mathrm{Ga}) \mathrm{Se}_{2}$ thin films, 14 Appl. Phys. Lett. 111 (2017) 32103

15 [26] D.F. Marron, Th. Glatzel, A. Meeder, Th. Schedel-Niedrig, S. Sadewasser, M.Ch. Lux-Steiner, 16 Electronic structure of secondary phases in $\mathrm{Cu}$-rich $\mathrm{CuGaSe}_{2}$ solar cell devices, Appl. Phys. Lett. 85 $17 \quad$ (2004) $3755-3757$

18 [27] D.F. Marron, A. Meeder, U. Bloeck, P. Schubert-Bischoff, N. Pfander, R Wurz, S. M.Babu, Th. 19 Schedel-Niedrig, M.Ch. Lux-Steiner, Microstructural properties of CVD-grown $\mathrm{CuGaSe}_{2}$ based thin 20 film solar cells, Thin Solid Films 431-432 (2003) 237-341

21 [28] H. Marko, L. Arzel, A. Darga, N. Barreau, S. Noël, D. Mencaraglia, J. Kessler, Influence of Cu off22 stoichiometry on wide band gap CIGSe solar cells, Thin solid films 519 (2011) 7228-7231 
1 [29] S. Nishiwaki, S. Siebentritt, M. Giersig, M.Ch. Lux-Steiner, Growth model of grains in a Cu-

2 rich/Cu-poor bilayer process, J. Appl. Phys. 94 (2003) 6864-6870

3 [30] T. Godecke, T. Haalboom, F. Ernst, Phase equilibria of Cu-In-Se. I Stable states and equilibrium $4 \quad$ stats of the $\mathrm{In}_{2} \mathrm{Se}_{3}-\mathrm{Cu}_{2} \mathrm{Se}$ system, Z Metallkd 91 (8) (2000) 622-634

5 [31] T. Haalboom, T. Gödecke, F. Ernst, M. Rühle, R. Herberholz, H. W. Schock, C. Berlharz, K. 6 W.Berz, Phase relations and microstructure in bulk materials and thin film of ternary system Cu-In$7 \mathrm{Cu}$, Proceedings of the Int. Conf. on Ternary and Multinary Compounds, Inst. Phys. Conf. ser. No 8 152: Section B: Thin Film Growth and Characterization (1997) 249-252

9 [32] R. Herberholz, U. Rau, H. W. Schock, T. Haalboom, T. Gödecke, F. Ernst, C. Beilharz, K. W. 10 Benz, D. Cahen, Phase segregation, Cu migration and junction formation in $\mathrm{Cu}(\mathrm{In}, \mathrm{Ga}) \mathrm{Se}_{2}$, Eur. 11 Phys. J. AP 6 (1999) 131-139

12 [33] L. S. Palatnik, E. K. Belova, Atroshch.Lv and Y. F. Komnik, Sov Phys Crystallogr 10 (4) (1966) $13 \quad 395$

14 [34] J.C. Mikkelson, Ternary phase relations of the chalcopyrite compound $\mathrm{CuGaSe}_{2}$, J. Electron. Mater. $10(1981) 541-558$

[35] J. Kessler, J. Schöldström, L. Stolt, Rapid Cu(ln, Ga)Se 2 growth using “End Point Detection”, Conf. Rec. IEEE Photovolt. Spec. conf. 2000-January (2000) 509-512

[36] O. Lundberg, J. Lu, A. Rockett, M. Edoff, L. Stolt, Diffusion of indium and gallium in $\mathrm{Cu}(\mathrm{In}, \mathrm{Ga}) \mathrm{Se}_{2}$ thin film solar cells, J. Phys. Chem. Solids 64 (2003) 1499-1504

[37] B. Namnuan, K. Yoodee, S. Chatraphorn, Probig diffusion of In and $\mathrm{Ga}$ in $\mathrm{CuInSe}_{2} / \mathrm{CuGaSe}_{2}$ bilayer thin films by X-ray diffraction, J Crys. Growth 432 (2015) 24-32

[38] F. Hergert, S. Jost, R. Hock, M. Purwins, A crystallographic description of experimentally identified formation reactions of $\mathrm{Cu}(\mathrm{In}, \mathrm{Ga}) \mathrm{Se}_{2}$, J. Solid State Chem. 179 (2006) 2394-2415 
1 [39] J. Lehmann, S. Lehmann, I. Lauermann, T. Rissom, C.A. Kaufmann, M. Ch. Lux-Steiner, M. Bär,

2 S. Sadewasser, Reliable wet-chemical cleaning of natively oxidized high-efficiency $\mathrm{Cu}(\mathrm{In}, \mathrm{Ga}) \mathrm{Se}_{2}$

3 thin film solar cell absorbers, J. Appl. Phys. 116 (2014) 233502

4 [40] K.H Kim, K.H. Yoon, J.H Yun, B.T. Ahn, Effects of Se flux on the microstructure of Cu(In, Ga)Se

5 thin film deposited by a three-stage co-evaporation process, Electrochem. Solid-State Lett. 9 (2006)

$6 \quad 382-384$

7 [41] A. Rockett, Surface analysis of chalcopyrite materials for photovoltaics, Progr. Photovolt. Res. $8 \quad$ Appl. $20(2012)$ 575-581

9 [42] D. Papadimitriou, N. Esser, C. Xue, Structural properties of chalcopyrite thin films studied by 10 Raman spectroscopy, Phys. Status Solidi 242 (2005) 2633-2643

11 [43] W. Witte, R. Kniese, M. Powalla, Raman investigations of $\mathrm{Cu}(\mathrm{In}, \mathrm{Ga}) \mathrm{Se}_{2}$ thin films with various copper contents, Thin solid Films 517 (2008) 867-569

13 [44] W. Witte, R. Kniese, A. Eicke, M. Pawolla, Influence of Ga content on the Mo/Cu(In, Ga)Se 2 14 interface formation, 2006 IEEE $4^{\text {th }}$ World Conference on Photovoltaic Energy Conference, 15 Waikoloa, HI, (2006) 553-556

16 [45] C. Xue, D. Papadimitriou, Y.S. Raptis, W. Richter, N. Esser, S. Siebentritt, M. Ch. Lux-Steiner, 17 Micro-Raman Study of Orientation Effects of Crystallites on Cu-rich Thin Films, J. Appl. Phys. 96, $18 \quad$ (2004) 1963-1966

19 [46] D. Drouin, A.R. Couture, D. Joly, X. Tastet, V. Aimez, R. Gauvin, CASINO V2.42-A fast and 20 Easy-to-use modeling tool for scanning electron Microscopy and microanalysis Users, Scanning 29 $21 \quad$ (2007) 92-101 
1 [47] T. Maeda, W. Gong, T. Wada, Crystallographic and optical properties and band structures of

$2 \mathrm{CuInSe}_{2}, \mathrm{CuIn}_{3} \mathrm{Se}_{5}$, and $\mathrm{CuIn}_{5} \mathrm{Se}_{8}$ phases in $\mathrm{Cu}$-poor $\mathrm{Cu}_{2} \mathrm{Se}_{-} \mathrm{In}_{2} \mathrm{Se}_{3}$ pseudo-binary system J. Appl.

$3 \quad$ Phys. 55 (2016) 04ES15

4 [48] C. Beilharz, Charakterisierung von aus der Schmelze gezüchteten Kristallen in den Systemen

$5 \quad$ Kupfer-Indium-Selen und Kupfer-Indium-Gallium-Selen für photovoltaische Anwendungen, Shaker

$6 \quad$ Verlag (1999)

7 [49] H. Dittrich, U. Prinz, J. Szot, H. W. Schock, Analysis of reaction kinetics of selenized CuInSe ${ }_{2}$ and $8 \quad \mathrm{CuGaSe}_{2}$ thin films, Proc. 9th EC Photovoltaic Solar Energy Conf. (1989) 163-166

9 [50] S. Kim, W.K. Kim, R. M. Kaczynski, R.D. Acher, S. Yoon, T.J. Anderson, O. D. Crisalle, E.A. 10 Payzant, S.S. Li, Reaction kinetics of $\mathrm{CuInSe}_{2}$ thin films grown from bilayer InSe/CuSe precursors, 11 J. Vac. Sci. Techn. A Vacuum, Surfaces, Films 23 (2005) 310-315

12 [51] W. K. Kim, E.A. Payzant, S. Kim, S.A. Speakman, O. D. Crisalle, T.J. Anderson, Reaction kinetics 13 of $\mathrm{CuGaSe}_{2}$ formation from a GaSe/CuSe bilayer precursor film, J. Cryst. Growth 310 (2008) 29872994

[52] Polyxeni Tsoulka, Adrien Rivalland, Ludovic Arzel, Nicolas Barreau, Improved $\mathrm{CuGaSe}_{2}$ absorber properties through a modified co-evaporation process, Thin Solid Films (2020), "accepted"

[53] Polyxeni Tsoulka, Local inhomogeneities in polycrystalline wide band gap $\mathrm{CuIn}_{1-\mathrm{x}} \mathrm{Ga}_{\mathrm{x}} \mathrm{Se}_{2}$ thinfilms, PhD Thesis, Nantes (2019)

[54] M. Marudachalam, R.W. Birkmire, H. Hichri, J.M. Schultz, A. Swartzlander, M.M. Al-Jassim, Phases, morphology, and diffusion in $\mathrm{CuIn}_{x} \mathrm{Ga}_{1-\mathrm{x}} \mathrm{Se}_{2}$ thin films, J. Appl. Phys. 82 (1997) 2896-2905

[55] N. Barreau, T. Painchaud, F. Couzine-Devy, L. Arzel, J. Kessler, Recrystallization of CIGSe layers grown by three-step processes: A model based on grain boundary migration, Acta Mater. 58 (2010) $5572-5577$ 
1 [56] F. Couzinie-Devy, N. Barreau, J. Kessler, Re-investigation of preferential orientation of

$2 \mathrm{Cu}(\mathrm{In}, \mathrm{Ga}) \mathrm{Se}_{2}$ thin films grown by the three-stage process, Prog. Photovolt: Res. Appl. 19 (2011) $3 \quad 527-536$

4 [57] J. Kessler, C. Chityuttakan, J. Lu, J. Schöldström, L. Stolt, $\mathrm{Cu}(\mathrm{In}, \mathrm{Ga}) \mathrm{Se}_{2}$ Thin films Grown with a 5 Cu-Poor/Rich/Poor Sequence: Growth model and structural considerations, Prog. Photovolt: Res. $6 \quad$ Appl. $11(2003)$ 319-331

7 [58] G. Hanna, J. Mattheis, V. Laptev, Y. Yamamoto, U. Rau, H.W. Schock, Influence of the selenium 8 flux on the growth of $\mathrm{Cu}(\mathrm{In}, \mathrm{Ga}) \mathrm{Se}_{2}$ thin films, Thin Solid Films 431-432 (2003) 31-36

9 [59] N. Ott, G. Hanna, U. Rau, J.H. Werner, H.P. Strunk, Texture of $\mathrm{Cu}(\mathrm{In}, \mathrm{Ga}) \mathrm{Se}_{2}$ thin films and 10 nanoscale cathodoluminescence, J. Phys. Condens. Matter 16 (2004) 85-89

11 [60] S. Ishizuka, A. Yamada, P.J. Fons, H. Shibata, S. Niki, Structural tuning of wide-gap chalcopyrite $12 \mathrm{CuGaSe}_{2}$ thin films and highly efficient solar cells: differences from narrow-gap $\mathrm{Cu}(\mathrm{In}, \mathrm{Ga}) \mathrm{Se}_{2}$, Prog. 13 Photovolt. Res. Appl. 22 (2013) 821-829

14 [61] V. Deprédurand, T. Bertram, D. Regesch, B. Henx, S. Siebentritt, The influence of Se pressure on 15 the electronic properties of $\mathrm{CuInSe}_{2}$ grown under Cu excess, Appl. Phys. Lett. 105 (2014) 172104

16 [62] M. Marudachalam, H. Hichri, R. Klenk, R.W. Birkmire, W.N. Shafarman, J. M. Schultz Preparation 17 of homogeneous $\mathrm{Cu}(\mathrm{In}, \mathrm{Ga}) \mathrm{Se}_{2}$ films by selenization of metal precursors in $\mathrm{H}_{2} \mathrm{Se}$ atmosphere Appl. $18 \quad$ Phys. Lett. 67 (1995) 3978-3980 


\section{List of figures}

Figure 1: SEM surface images of the CIGSe layers: $\# 01$ with $\mathrm{x}=0.30$ (left) and $\# 02$ with $\mathrm{x}=0.60$ (right) without post-deposition treatment

Figure 2: SEM surface images of CIGSe films, after the KCN surface etching and annealing under vacuum: \#01 with $\mathrm{x}=0.30$ (left) and \#02 with $\mathrm{x}=0.60$ (right)

Figure 3: Raman analysis of the CIGSe films \#01 with $x=0.30$ (a) and \#02 with $x=0.60$ (b). The black lines correspond to the Raman spectra of the samples without any post-deposition treatment. The red lines represent the samples after the $\mathrm{KCN}$ etching and annealing. The peak that corresponds to the copper selenide phase is highlighted in yellow

Figure 4: XRD analysis of $\mathrm{x}=0.30$ (\#01, (a)) and $\mathrm{x}=0.60 \quad(\# 02$, (b)) CIGSe layers grown on SLG/SiN/Mo. The black lines illustrate the diffractogram of the final CIGSe layers obtained after the end of the two-stage co-evaporation process and they did not undergo any post-deposition process. The red lines show the diffractogram obtained for the CIGSe samples after the KCN surface etching and annealing under vacuum for 30 days at $350^{\circ} \mathrm{C}$

Figure 5: Schematic representation of the copper selenide surface segregation and bulk precipitation in the case of $i$ ) In-rich CIGSe and ii) Ga-rich CIGSe absorber layers. At the In-rich sample after the end of the CIGSe growth the copper selenide has entirely segregate at the surface of the film. Hence the removal of the copper selenide phases from the surface leaves a homogeneous CIGSe film without any detrimental $\mathrm{Cu}$-rich secondary phases. At the Ga-rich sample, the duration of the deposition process is not sufficient to homogenize the film and make the copper selenide compounds segregate at the surface. As a result, after the end of the deposition process, there are $\mathrm{Cu}$-enriched bulk precipitates within the bulk of the absorber layer, that they cannot be removed by the KCN treatment. A long annealing under vacuum is then required for the $\mathrm{Ga}$ rich absorber to make the entire $\mathrm{Cu}_{\delta} \mathrm{Se}$ segregate at the surface

Figure 6: SEM surface images of CGSe Cu-rich layer (\#03) deposited on Mo, (a) after the coevaporation without post-deposition treatment, (b) after annealing at $350^{\circ} \mathrm{C}$ for $24 \mathrm{~h}$ under vacuum and (c) high-magnification image of the sample after annealing at $350^{\circ} \mathrm{C}$ for $24 \mathrm{~h}$

Figure 7: Left: SEM surface image coupled with EDS surface cartography (at 5kV acceleration voltage) of the In-free CGSe film (\#03) after annealing. Right: The elemental concentration of the two grains highlighted by the dotted circles in the SEM image. The red curve in the EDS spectrum corresponds to a stoichiometric CGSe region while the yellow curve represents a $\mathrm{Cu}$-enriched region and the presence of copper selenide secondary phases

Figure 8: XRD analysis of a CGSe sample (\#04, y=0.95) grown on SLG/Mo by two-stage coevaporation process $(\mathrm{Cu}-\mathrm{RO})$. The diffractogram does not present any $\mathrm{Cu} \delta \mathrm{Se}$ peak. The y axis represents the logarithm of the intensity

Figure 9: SEM-EDS cross-section elemental profile of a CGSe sample (\#04, y=0.95) grown on Mo by a two-stage co-evaporation process $(\mathrm{Cu}-\mathrm{RO})$. The EDS measurement was performed at $10 \mathrm{kV}$ beam acceleration voltage

\section{$38 \quad$ List of tables}

Table I: Summary of the elemental concentration $\mathrm{x}=[\mathrm{Ga}] /([\mathrm{Ga}]+[\mathrm{In}])$ and $\mathrm{y}=[\mathrm{Cu}] /([\mathrm{Ga}]+[\mathrm{In}])$ measured by EDS at $20 \mathrm{kV}$ acceleration voltage, the substrate, the CIGSe co-evaporation process and the postdeposition treatment (KCN etching and annealing) of each sample. The $\mathrm{y}_{\mathrm{R}}, \mathrm{y}$ and $\mathrm{y}_{\mathrm{A}}$ denote the $\mathrm{Cu}$ content at the end of the $\mathrm{Cu}$-rich stage, after the end of the co-evaporation process and after the annealing respectively. The error at the atomic percentage is \pm 0.03 


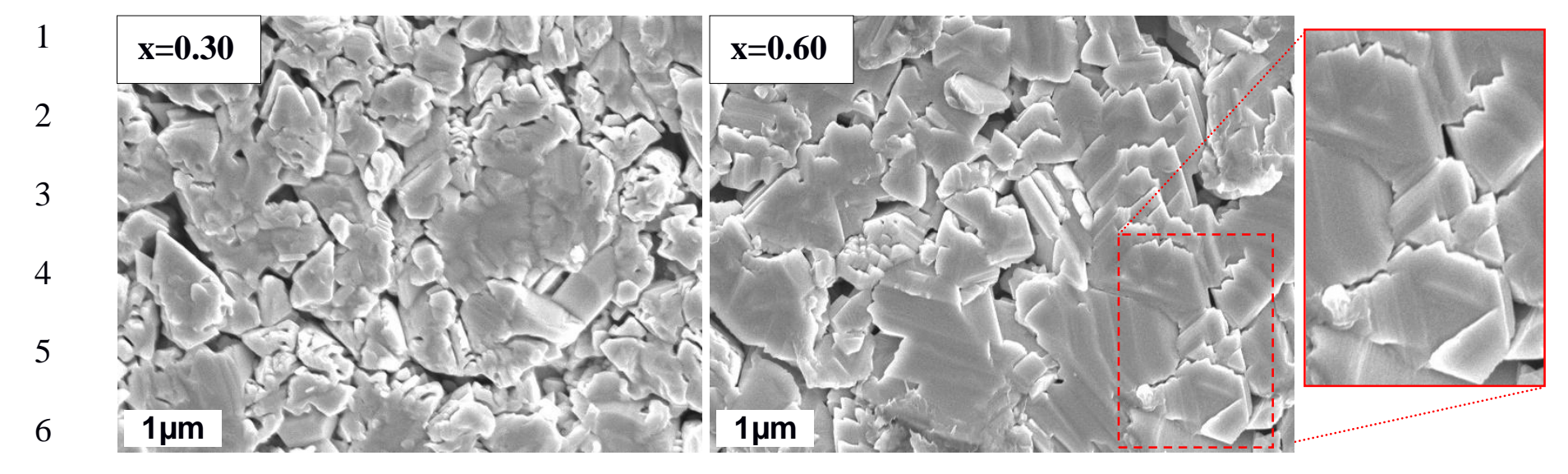

7 Figure 1: SEM surface images of the CIGSe layers: \#01 with $x=0.30$ (left) and \#02 with $x=0.60$ (right) 8 without post-deposition treatment 

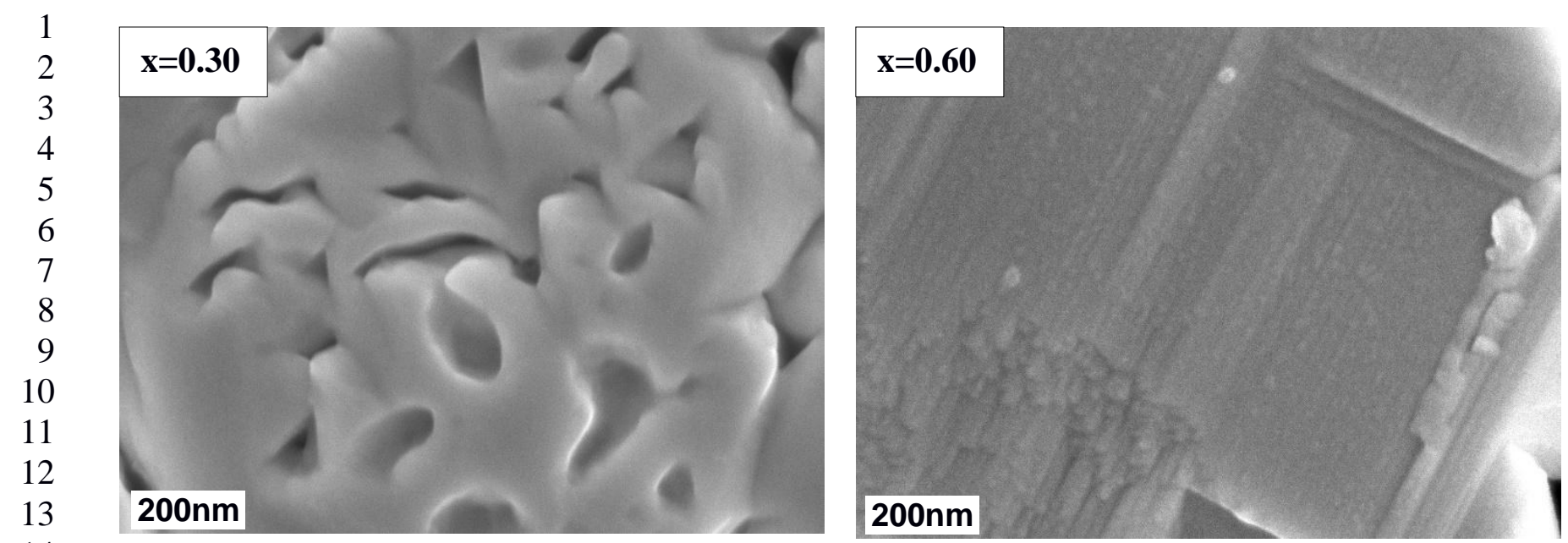

14

15

Figure 2: SEM surface images of CIGSe films, after the KCN surface etching and annealing under 16 vacuum: \#01 with $x=0.30$ (left) and \#02 with $x=0.60$ (right) 

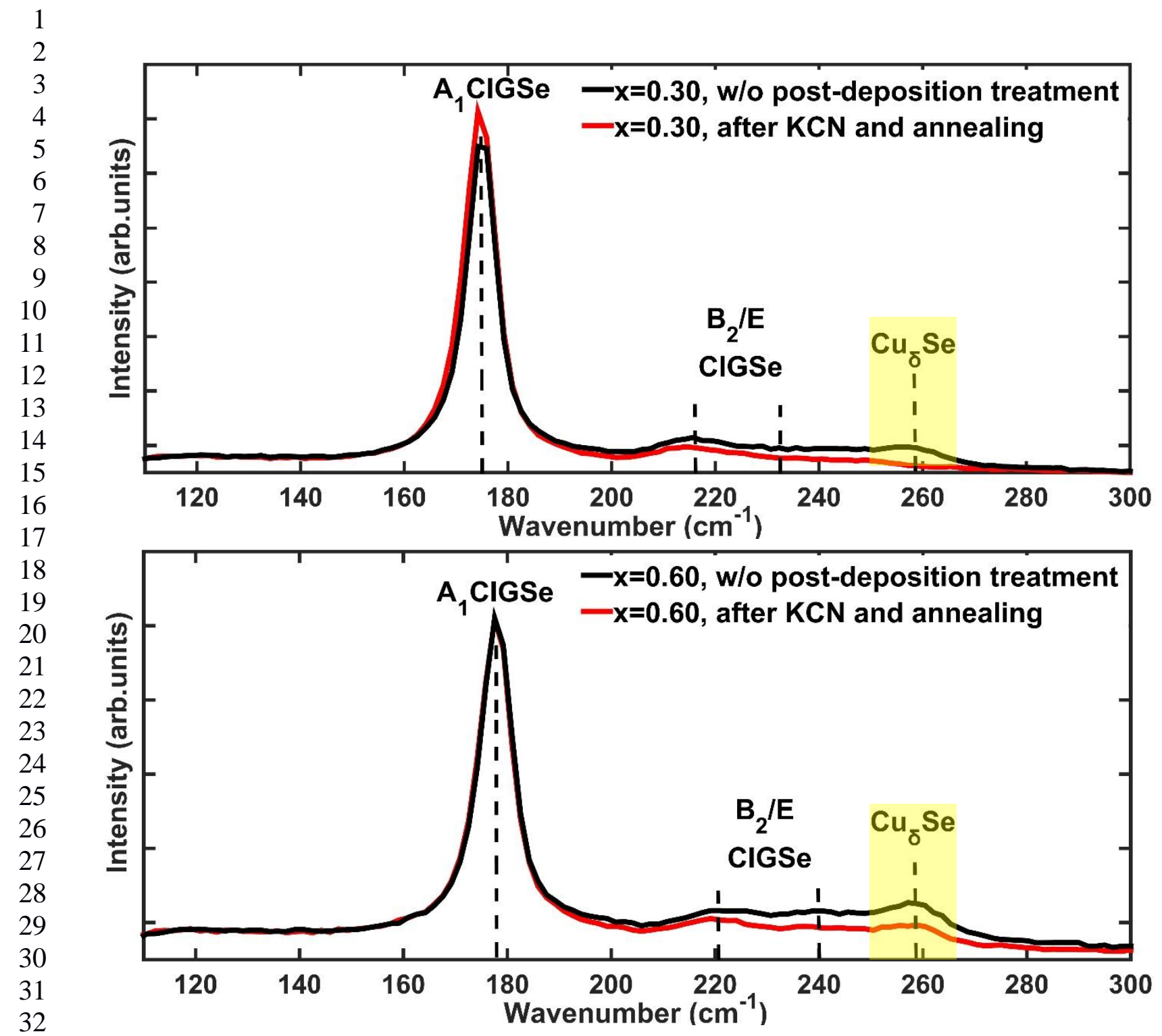

Figure 3: Raman analysis of the CIGSe films \#01 with $x=0.30$ (a) and \#02 with $x=0.60$ (b). The black lines correspond to the Raman spectra of the samples without any post-deposition treatment. The red lines represent the samples after the $\mathrm{KCN}$ etching and annealing. The peak that corresponds to the copper selenide phase is highlighted in yellow 


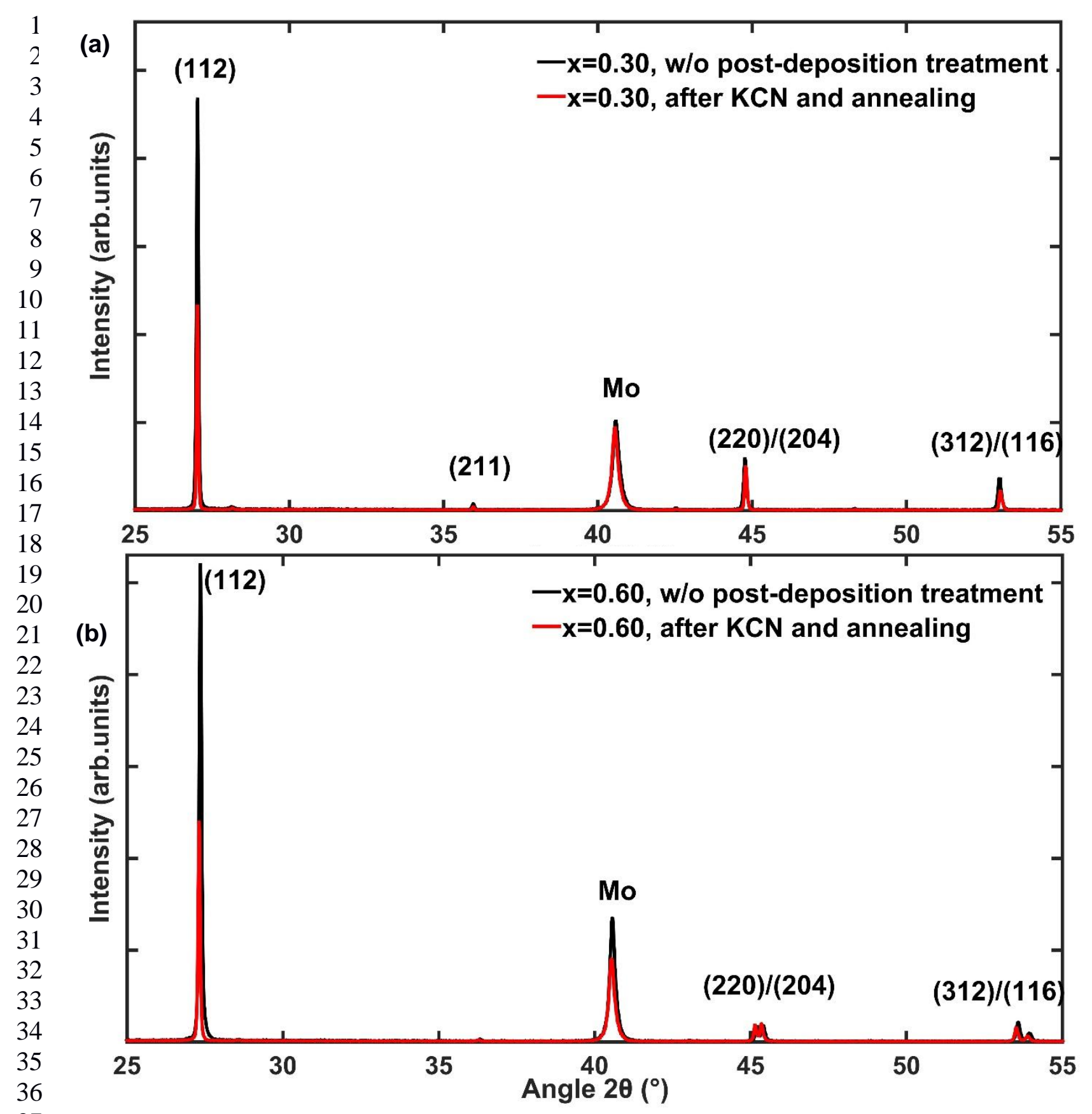

Figure 4: XRD analysis of $x=0.30(\# 01,(a))$ and $x=0.60(\# 02,(b))$ CIGSe layers grown on $S L G / S i N / M o$. The black lines illustrate the diffractogram of the final CIGSe layers obtained after the end of the two-stage co-evaporation process and they did not undergo any post-deposition process. The 


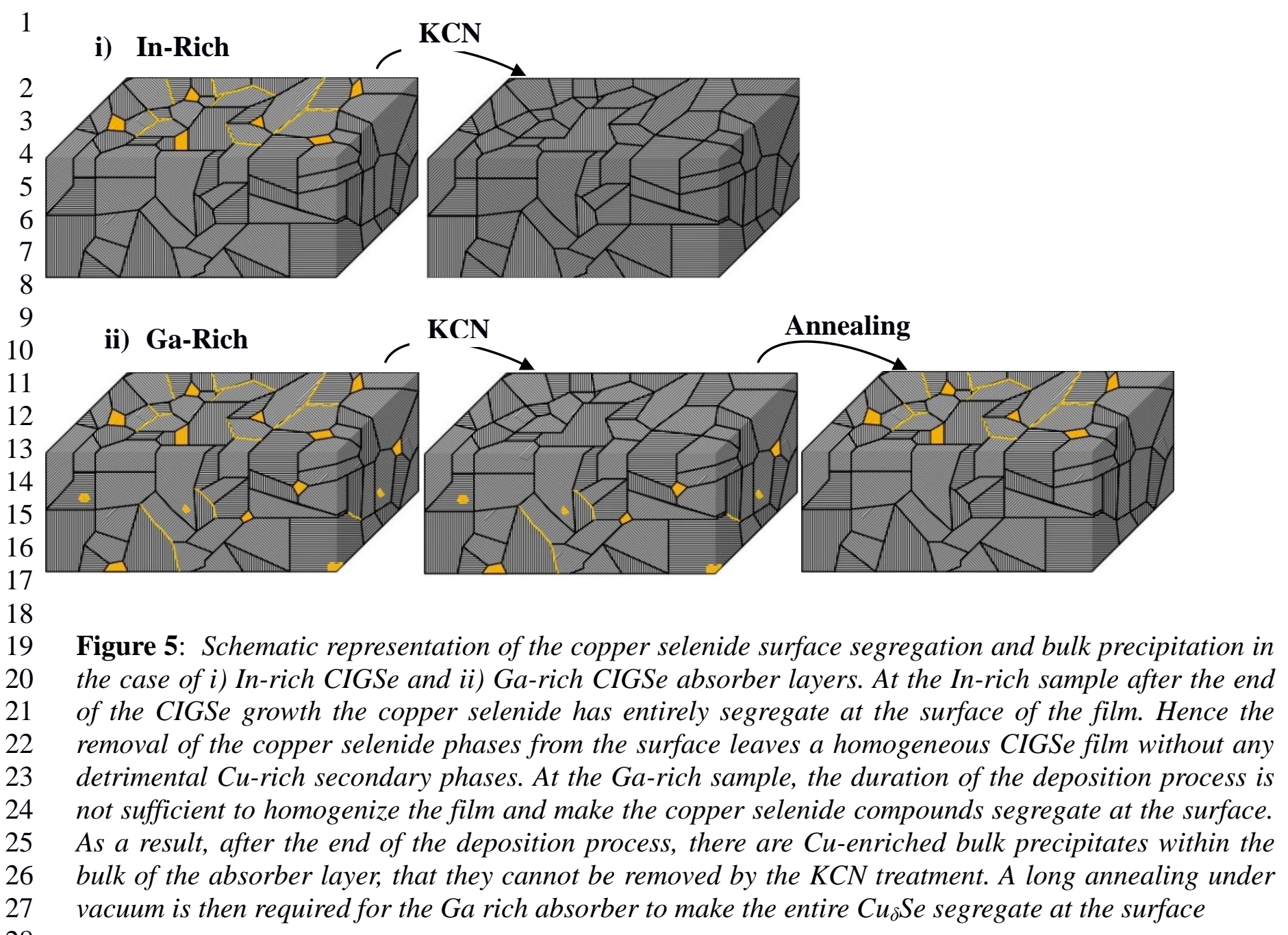



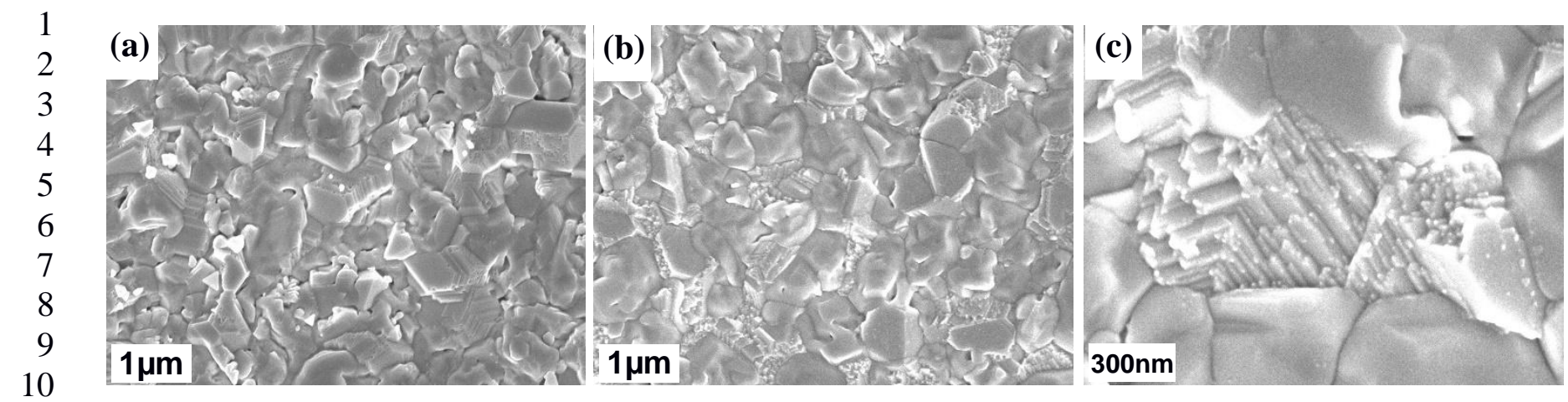

11 Figure 6: SEM surface images of CGSe Cu-rich layer (\#03) deposited on Mo, (a) after the co12 evaporation without post-deposition treatment, (b) after annealing at $350^{\circ} \mathrm{C}$ for $24 \mathrm{~h}$ under vacuum and 13 (c) high-magnification image of the sample after annealing at $350^{\circ} \mathrm{C}$ for $24 \mathrm{~h}$ 

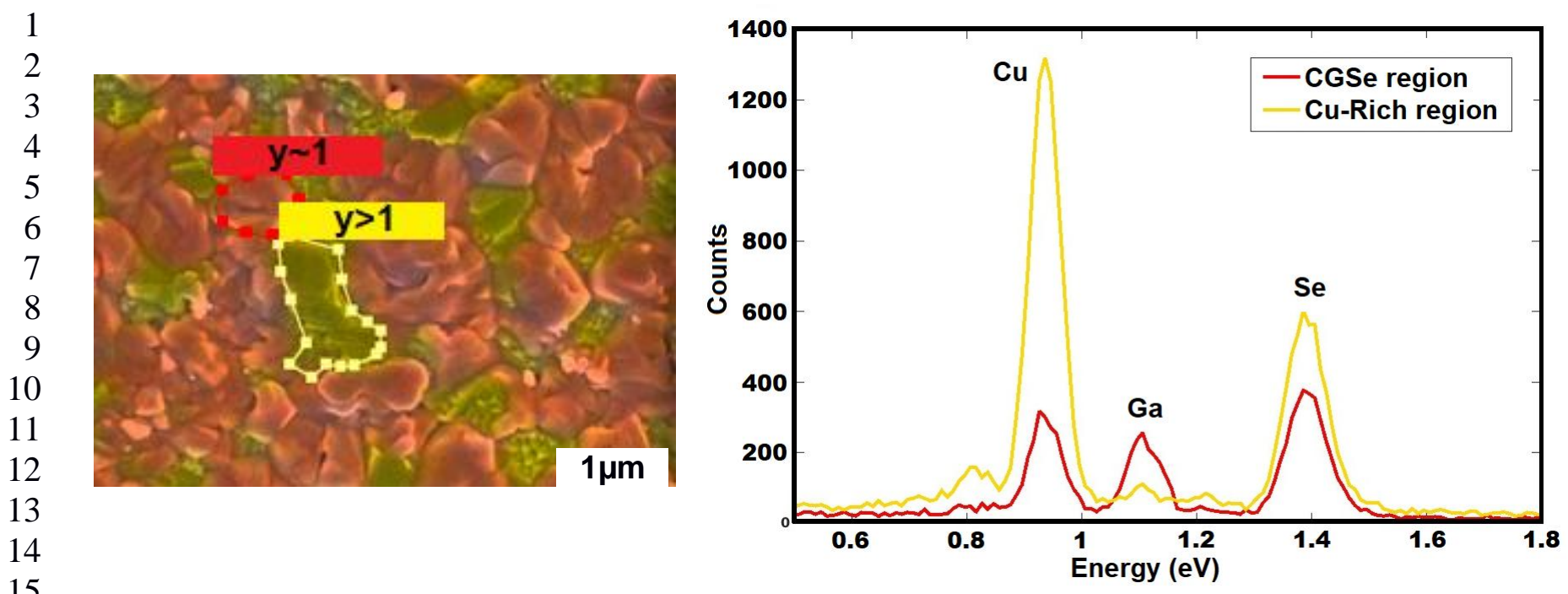

Figure 7: Left: SEM surface image coupled with EDS surface cartography (at $5 \mathrm{kV}$ acceleration voltage) 17 of the In-free CGSe film (\#03) after annealing. Right: The elemental concentration of the two grains 18 highlighted by the dotted circles in the SEM image. The red curve in the EDS spectrum corresponds to a 19 stoichiometric CGSe region while the yellow curve represents a Cu-enriched region and the presence of 20 21 


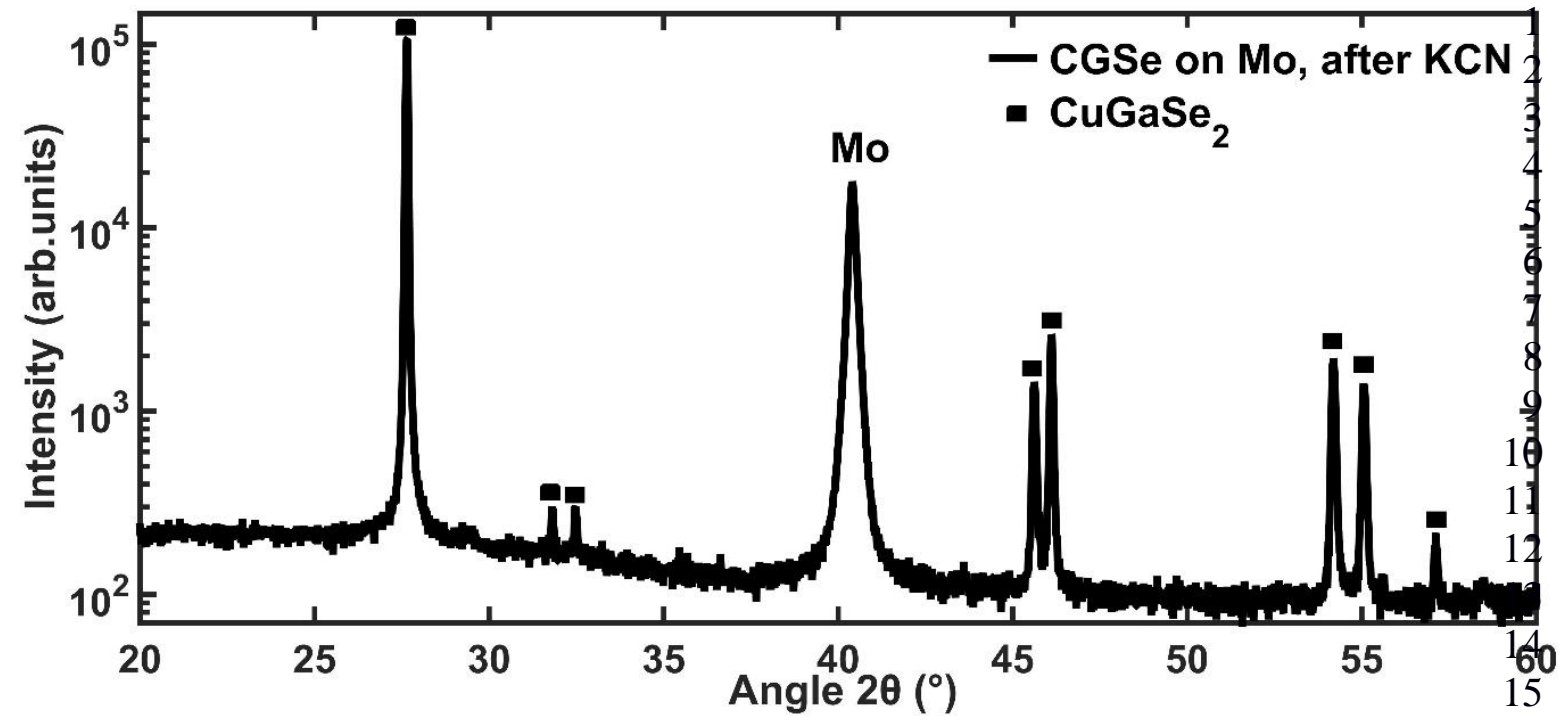

16 Figure 8: XRD analysis of a CGSe sample (\#04, y=0.95) grown on SLG/Mo by two-stage co17 evaporation process $(\mathrm{Cu}-\mathrm{RO})$. The diffractogram does not present any $\mathrm{Cu}$ Se peak. The y axis represents 18 the logarithm of the intensity 


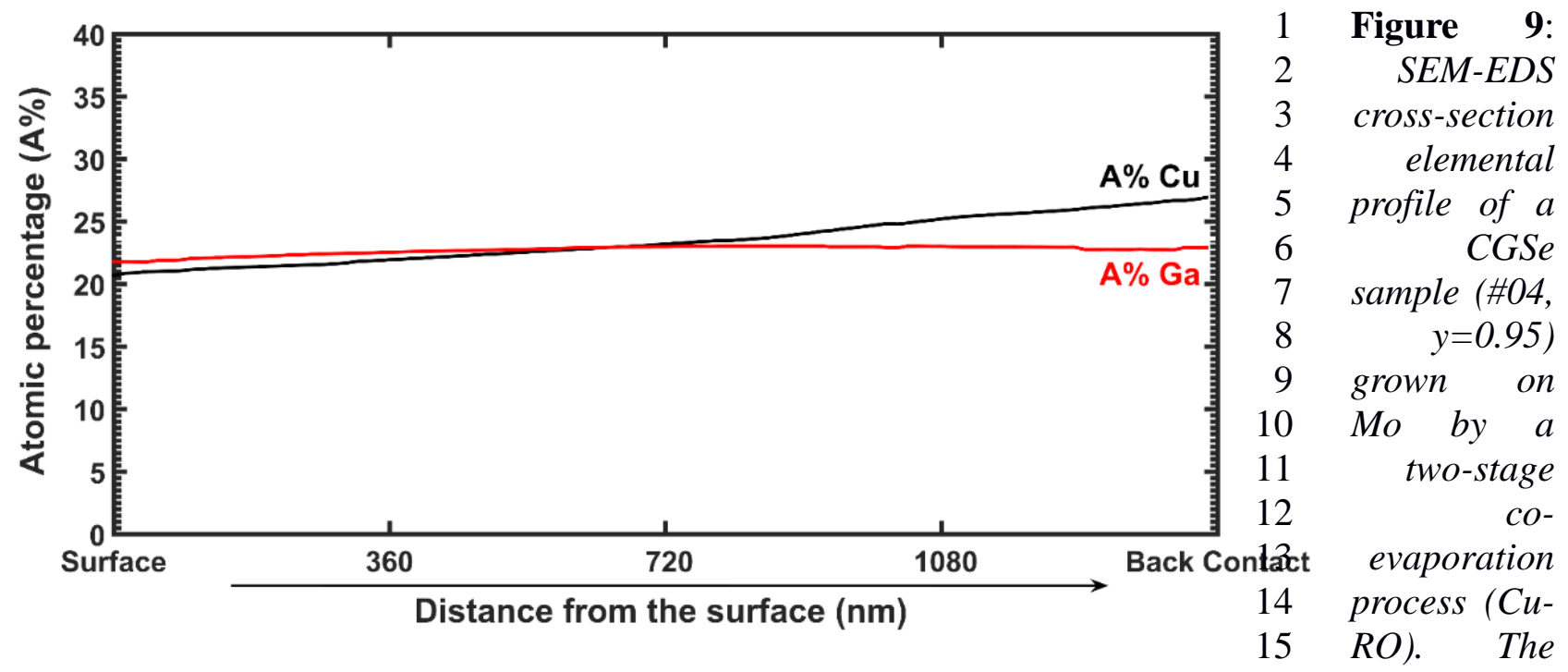

16 EDS measurement was performed at $10 \mathrm{kV}$ beam acceleration voltage

17

18 
1 Table I: Summary of the elemental concentration $x=[\mathrm{Ga}] /([\mathrm{Ga}]+[\mathrm{In}])$ and $y=[\mathrm{Cu}] /([\mathrm{Ga}]+[\mathrm{In}])$ 2 measured by EDS at $20 \mathrm{kV}$ acceleration voltage, the substrate, the CIGSe co-evaporation process and 3 the post-deposition treatment (KCN etching and annealing) of each sample. The $y_{R}, y$ and $y_{A}$ denote the $4 \mathrm{Cu}$ content at the end of the Cu-rich stage, after the end of the co-evaporation process and after the 5 annealing respectively. The error at the atomic percentage is \pm 0.03

6

\begin{tabular}{ccccccccc}
\hline sample & $\mathbf{x}$ & $\mathbf{y}_{\mathbf{R}}$ & $\mathbf{y}$ & $\mathbf{y}_{\mathbf{A}}$ & Substrate & $\begin{array}{c}\text { Co-evaporation } \\
\text { process }\end{array}$ & $\begin{array}{c}\text { KCN } \\
\text { etching }\end{array}$ & Annealing \\
\hline$\# 01$ & 0.30 & 1.36 & 0.98 & 0.92 & $\mathrm{SLG} / \mathrm{Si}{ }_{\mathrm{X}} \mathrm{N} / \mathrm{Mo}$ & $\mathrm{Cu}-\mathrm{RO}$ & $\mathrm{YES}$ & 30 days \\
\hline$\# 02$ & 0.60 & 1.39 & 0.87 & 0.86 & $\mathrm{SLG} / \mathrm{Si}{ }_{\mathrm{x}} \mathrm{N} / \mathrm{Mo}$ & $\mathrm{Cu}-\mathrm{RO}$ & $\mathrm{YES}$ & 30 days \\
\hline$\# 03$ & 1.00 & - & 1.50 & - & $\mathrm{SLG} / \mathrm{Mo}$ & $\mathrm{Cu}-\mathrm{R}$ & $\mathrm{NO}$ & 24 hours \\
\hline$\# 04$ & 1.00 & - & 0.95 & - & $\mathrm{SLG} / \mathrm{Mo}$ & $\mathrm{Cu}-\mathrm{RO}$ & $\mathrm{YES}$ & -
\end{tabular}

$7 \quad{ }^{1}$ For the annealing of 30 days the samples were sealed under vacuum in quartz tubes. The annealing of 824 hours was carried out in a chamber under vacuum 